\title{
Two Fungi, parasitic on species of Toly. pothrix (Resticularia nodosa, Dang. and R. Boodlei, n. sp.).
}

\author{
F. E. FRITSCH, B.Sc., PH.D., F.L.S. \\ Demonstrator in Botany, University College, London.
}

With Plate XXIX.

THE researches of the last twenty years have shown that there are a considerable number of Fungi which infest algal hosts and generally cause considerable havoc amongst them. Lemmermann ('01) has recently enumerated I93 such forms, which belong chiefly to the Chytridineae and the Ancylistaceae. With a member of this latter order we are concerned in the present paper.

The genus Resticularia was first established by Dangeard in I890 for a Fungus, parasitic in Lyngbya aestuarii. Since that time no further contribution towards our knowledge of the genus has, as far as I am aware, been published. Dangeard's genus has been accepted by Fischer ('92, p. 84) and by Schröter ('93, p. 92), both authors placing it next to the genus Ancylistes of Pfitzer.

Dangeard's Resticularia nodosa (Dangeard, '90) assumes the form of a straight tube, which is frequently appreciably enlarged within each cell of the Alga, so that in its entirety

[Annals of Botany, Vo1. XVII. No. LXVIII. September, 1903.] 
the parasitic mycelium presents a moniliform appearance. The mycelium, although as a rule simple, is occasionally somewhat branched; and by means of such branches, emerging from the algal threads into the surrounding medium, infection from one filament to another readily takes place ${ }^{1}$. Occasionally uniciliate zoospores of relatively large size and moving actively are produced ; these ultimately come to rest on the Alga and germinate immediately. According to Dangeard's view, a sexual process also takes place, leading to the formation of thick-walled zygospores, which are generally spherical but sometimes elongate-elliptical in shape, and which are often formed in considerable numbers in the same algal filament. The germination of these zygospores was not observed.

I have observed a species, which is probably identical with the Resticularia nodosa of Dangeard, although differing in a number of points from the author's original description. Further, a new species from the Pen Ponds, Richmond Park, will be described, which I have great pleasure in naming after its collector, Mr. L. A. Boodle, F.L.S.

\section{Resticularia nodosa, Dangeard (?).}

This Fungus was first observed in a species of Tolypothrix, growing on rocks in the Nepenthes-house at Kew, in October of last year. At this time many of the filaments of the Alga were infested by the parasite (Figs. 19-23). The latter formed long chains of cells within its host, each link of the chain generally occupying one of the algal cells. The successive cells in the chain were separated from one another by true transverse walls, which seem, however, to arise after the constriction of the fungal hypha has taken place. The shape of the cells of the parasite is very varied, and it appears more or less to adapt itself to the size of the surrounding algal cell. Usually each segment of the Fungus has an elongated elliptical outline (Figs. I9-2I), frequently with one or both ends considerably dilated; the cells may, however, also be oval or

${ }_{1}^{1}$ Dangeard does not figure any such infection. 
almost spherical (Fig. 26). Usually the constrictions, and therefore also the transverse walls of the Fungus correspond in position with the dividing septa of the algal filament; this is due to the narrowing down of the fungal hypha, when it has to pass through a wall of the Alga. Not infrequently the Fungus branches within the host (Figs. 24, 25) and a very complicated tangle may sometimes be formed in this way (Fig. 26).

The contents of the fungal segments are colourless, and consist of vacuolar protoplasm with one or more bright granules of some oily substance. I was not able to make out nuclei. The effect on the cell-contents of the Alga was in the first place decolourizing. It would appear that the action of the Fungus does away with the special colouring-matter of the Tolypothrix-cells, so that those which have been recently attacked have a dirty yellowish-green colour. But even this soon disappears, and ultimately the entire cell-contents, as well as the dividing-walls of the Alga, are dissolved away. In the earlier stages of this process the contracted protoplasm forms a kind of granular sack round the fungal cell (Figs. I9, 20).

The most striking point about this Fungus, and a point in which it differs from the species to be described below, is the frequent occurrence of thick-walled dark brown cells in the course of the parasitic hyphae; such cells are to be seen in all my figures of this species. These spores were formed in considerable numbers in the course of each hypha ; they were most commonly single (Figs. 2I, 24), often in twos (Figs. $22,23)$, and sometimes aggregated together in large numbers. Apparently any cell of the Fungus could develop into one of these spores, but there seemed a great tendency for their formation inside the heterocysts of the Alga (Fig. 20), probably because the conditions of nourishment are worse there than in the other cells of the filament. The heterocysts present a considerable obstruction to the passage of the Fungus, and in many cases the latter was observed to terminate at these points (Fig. I9); sometimes these terminations 
were marked by the formation of a group of the thick-walled spores, abutting directly on the heterocyst.

These spores arise in the following way: a single segment of the Fungus increases somewhat in size and acquires a thicker wall. This is followed by the appearance of one or two large oily granules in its homogeneous contents (Fig. 27). Ultimately the wall differentiates into two layers and acquires a dark brown colour, and the number of oily granules present generally increases (Figs. 20, 26). The spores have very much the same shape as the fungal segment, from which they arise; generally a slight rounding-off takes place in their formation. These thick-walled cells are of the nature of chlamydospores; ultimately the remainder of the Fungus disappears and they alone remain, lying within the empty algal sheath (Fig. 22). They probably undergo a long period of quiescence before germination takes place.

Occasionally hyphae are formed as branches on the parasitic mycelium, which emerge from the Alga into the surrounding medium (Fig. 25). They are generally very delicate and show no trace of septation, although drops of oily matter, which to some extent simulate partition-walls, frequently occur in their course. I have no doubt that they serve to infect other (healthy) algal filaments, although I have been unable to obtain figures of such cases.

Except for the absence of zoospore-formation, the Fungus I have just described is in most essentials similar to the Resticularia nodosa of Dangeard. The latter observer considers the thick-walled spores ${ }^{1}$ to have arisen by a sexual process ; he remarks (Dangeard, '90, p. 98): 'La reproduction sexuelle se fait de la manière suivante: sur le trajet d'un même filament le protoplasma se condense par place comme le montrent les figures 29 et 30 ; on ne saurait faire aucune distinction entre le protoplasma mâle et le protoplasma femelle, bien qu'il y ait souvent l'une des portions un peu plus grosse que la seconde; le filament mycélien sur lequel se forment ces zygospores ne parait pas se cloisonner ; du moins,

\footnotetext{
1 Dangeard does not remark that the walls of the spores take on a brown colour.
} 
nous n'avons jamais réussi à voir une cloison quelconque 1' Dangeard's figures 29 and 30 give no indication of a fusion between protoplasmic masses or nuclei in the formation of the spores (with the possible exception of Fig. 30), nor does he state that he has seen anything of the kind. His assumption that they are sexually-formed zygospores is based on a comparison with Maxime Cornu's and with Zopf's figures of Myzocytium and Lagenidium respectively; and he adds that ' nous devons noter toutefois que la différenciation sexuelle est bien faible et que, dans beaucoup de cas, il devient impossible de la saisir' (loc. cit., p. 99).

Fischer ('92, p. 85) remarks that, according to Dangeard's description, 'die Sexualorgane in der Weise entstehen, dass in einem aufgeschwollenen Fadenstuick das Protoplasma sich in zwei gleiche Theile verdichtet, die mit einander verschmelzen und die Dauerspore (Zygospore) erzeugen.' Dangeard says nothing about a fusion, although, by his calling the thickwalled cells zygospores, he tacitly assumes its occurrence.

I can see no reason for regarding these spores as having been sexually produced. They are merely formed by an increase in size of a part of the ordinary mycelium, and the fact of their sometimes being formed in groups of three, four or five together alone speaks against their sexual origin; for there are no traces of empty antheridial cells between the individual spores in such cases. It is true that the young stages often have a sort of pear-shaped form, so that there are apparently a large and a small swelling side by side (cp. Fig. 18 of $R$. Boodlei); but in these cases the fully-developed spore has the same shape (Figs. 20, 2I), and I was unable to detect a differentiation into two protoplasmic masses in the earlier stages.

There is one further point, which I think speaks very strongly against the sexual origin of these spores. I have already mentioned that some branches of the parasitic hyphae

${ }^{1}$ It is not quite plain to me, whether Dangeard is referring to the entire hypha, in whose course the spore is formed, or to the non-occurrence of a division-wall between the assumed sexual organs; if the former is the case, this is a point of difference between $R$. nodos $a$ and the form I am describing. 
can leave the host and emerge into the surrounding medium. In some cases this external mycelium becomes very much branched, and spores, in all respects similar to those formed on the internal hyphae, are developed on it by a kind of budding-process. Short lateral branches of the unseptate mycelium swell up apically, thus becoming capitate (Fig. 27). In these swellings, as they increase in size, large oily granules appear, whilst the thickened membrane finally becomes differentiated into two layers and takes on a dark brown colour; the fully-developed chlamydospore is separated by a transverse wall from the mycelium on which it is borne (Fig. 28). The spores, formed in this way, are usually absolutely spherical and are attached by a short stalk-the unaltered portion of the lateral branch-to the mycelium. Such spores were formed in great numbers during the previous month; undoubtedly they go through a resting-period, but of what duration I am unable at present to say. A comparison of the figures will show that these spores differ in no respect from those formed internally, and here it is certainly impossible to assume the occurrence of a sexual process.

Although I have at present preferred not to give the Fungus just described a new name, it may turn out to be specifically distinct from $R$. nodosa, Dangeard. In this latter species branching is scarce, the spores contain a single large oil granule ${ }^{1}$ and are apparently only formed singly, and zoospore-formation is apparently common. The dimensions of the spores agree fairly well.

I give the following measurements of the Fungus described :

Diameter of internal (parasitic) mycelium $=.004-.006 \mathrm{~mm}$.

$$
" \quad \text { " external mycelium }=.0005^{-.001 ~ m m} \text {. }
$$

\section{Resticularia BOODLEI, NOV. SP.}

This species was found parasitic in the filaments of a Tolypothrix, which formed the most characteristic feature

${ }_{1}$ Dangeard found that the spores of $R$. nodosa later came to contain a number of oily granules (loc. cit., p. 98 ); he interprets this as a stage preceding germination. 
of the algal vegetation in the lower of the two Pen Ponds, Richmond Park, last November; since then the Alga has practically disappeared.

In the material collected in November, 1902, all the algal filaments presented a healthy appearance, and the only indication of the presence of the Fungus was to be found in the occurrence of numbers of colourless spores of relatively large size between the threads of the Tolypothrix. These spores had rather thin walls generally differentiated into two layers, and possessed clear, homogeneous contents (Fig. I) ; many of them had grown out at one or more points, giving rise to unseptate hyphae, which frequently followed the course of the algal filaments externally, not rarely enveloping them in a perfect mycelial web, which, however, remained purely epiphytic. In germination the external layer of the membrane is ruptured, and the contents surrounded by the internal layer grow out. One curious feature observed at this date remains to be mentioned. Some of the spores appeared to lie within the external layer of the Tolypothrix-sheath, a position for which I am unable to account (Fig. I).

In samples of the same Alga, collected a month later, it was at once apparent that some change had taken place. In many places the dark green colour of the Tolypothrix had given way to a dirty greenish-yellow, and all transitions between these two colours could be observed with the naked eye. A microscopic examination showed that now, in addition to the abundant epiphytic mycelium of the Fungus, large numbers of hyphae had penetrated into the interior of the Alga ${ }^{1}$; Fig. 2 shows a germinating spore, the hypha from which has pierced the sheath and grown for a short distance inside the host. Once successfully inside, the Fungus makes rapid progress, and large numbers of the algal filaments were found to contain long moniliform hyphae, like the one shown

${ }^{1}$ It is curious that a diligent search revealed no traces of parasitic hyphae a month before. Possibly the Fungus is only able to penetrate into the Alga, when the latter is in a low state of vitality. The way in which the filaments of the latter are enveloped by the epiphytic mycelium might alone tend to produce such a state; and thus ultimately make it possible for some hyphae to penetrate into the host. 
in Fig. 3. This moniliform shape of the parasitic hypha is due to the same cause as in $R$. nodosa, Dangeard; that is to say, the Fungus expands considerably within each cell of the Alga, narrowing down each time it has to penetrate one of the transverse walls of the latter. The Fungus itself at this stage either presents no partition-walls whatever, or they only occur at very rare intervals; this is readily discerned with a high power of the microscope. As the parasite grows on in front, it generally dies off behind, and the posterior portion is then cut off from the living anterior part by the successive formation of transverse walls ; these generally arise at the points where the constrictions occur (Figs. 8, I0). The living portion of the Fungus has perfectly homogeneous contents of an opaque white appearance, occasionally interrupted by small drops of oily matter of a highly refractive nature (Figs. 3, 7). Nuclei were not observed. The segments are most commonly ovate, but occasionally spherical. The Fungus only rarely pursues a straight course within the Alga; generally it is more or less zigzag or spiral ${ }^{1}$.

The Fungus has the same effect on the cell-contents of the Alga as the species first described ; in both cases no deformation of the algal filaments, such as Dangeard describes as occasionally occurring in the Lyngbya attacked by $R$. nodosa (cp. Dangeard, '90, p. 96), was observed. Fig. 3 shows the protoplasmic contents of the algal cell contracted around the segments of the parasite, whilst Figs. 4, 7, 8, \&c., show stages in which the Fungus alone remains within the sheath of the Tolypothrix.

Usually only a single fungal hypha is to be seen in each algal filament; in a very few cases branching was observed to take place, both branches continuing to live inside the host. On the other hand, external branches, i. e. branches which penetrate the sheath of the Alga and emerge into the surrounding water, are very common. Figs. 3 and 4 show early stages in the development of such branches, whilst Figs. 5, 6, and 7

1 In passing from one homogonium of the Alga to another the hypha narrows down and presents no constrictions (Fig. 8 ); cp. also Dangeard, loc. cit., p. 97. 
show them in the fully-developed condition. These external branches are generally somewhat narrowed down at the point where they pass through the algal sheath, expanding again as soon as they enter the water. Except for the absence of the regular constrictions, they in every way resemble the internal mycelium; transverse walls occasionally occur in their course. They are frequently branched and ramify in all directions in the water. The vegetative cells of the internal mycelium, from which they arise, are in no way especially modified.

When these hyphae come into contact with another healthy algal filament they frequently penetrate its sheath, and give rise to a parasitic mycelium within (Figs. IO, II). Such infecting hyphae ('Ansteckungshyphen') are one of the chief means of propagation of the Fungus, and constitute a strong point of resemblance to the genus Ancylistes, in which they occur abundantly. It should, however, be remarked that these hyphae were often seen to come into contact with a healthy filament of the Alga without attacking it. In some cases the hyphae arising from the parasite all grow out in one and the same direction, as though there were some stimulus regulating their formation and direction of growth.

The thick-walled heterocysts of the Alga (which in this species occurred in groups of 4-9 together), again presented a considerable obstruction to the passage of the Fungus, and not rarely seemed to form an unsurpassable barrier. Further, the Alga protects itself by the formation of thick transverse walls some little way in front of the momentary position of the Fungus ${ }^{1}$. Apparently these also form considerable obstacles to the growth of the latter, and in some few cases the Fungus was observed to emerge from the filament at such a point and to come in again on the other side (Figs. I3, I4), finding it easier to pass through the thick sheath than through the protecting wall formed by the Alga. To the difficulty of passing through a heterocyst must also be

1 Such protecting-walls were also, but rarely, seen in the case of the firstdescribed species. 
attributed the fact that the Fungus so frequently leaves the main filament for a branch at the points, where branching of the Tolypothrix occurs; it thus avoids the heterocyst, which is situated immediately above the point of branching.

A few anomalous cases were observed in connexion with the external mycelium. Thus Fig. 12 shows a hypha which has just emerged and has formed a number of branches, one of which is again penetrating into the same algal filament, whilst Fig. I 5 shows a case where the mycelial branch has re-entered the Alga and fused with the hypha from which it arose.

I have already mentioned that the external mycelium may be very much branched. In some cases it attains a great development and proceeds to form large numbers of spores. The mycelium then becomes septate and develops numerous lateral branches, which generally do not reach any considerable length. In these branches transverse walls are formed, so that they come to consist of a row of thin-walled cells. These increase in size, at the same time assuming an elliptical shape (Fig I6), and develop into the thin-walled spores, which were first seen in November last. In some cases the lateral branches are very short and only develop into a single spore, which is thus formed in a way very similar to the chlamydospores of the first described species.

In other cases the mycelium proceeds to form these spores immediately after emerging from the Alga, as is seen in Fig. I7; here the entire external mycelium has been transformed into spores. This is frequently the case, and when spores are thus formed from a strongly-branched and extensive mycelium we get enormous masses of them, many of which still show their origin from a row of cells. The spores are oval and generally slightly drawn out at one or both ends, owing to their previous position in a moniliform thread (cp. Fig. I6). When occurring in extensive masses the shape of the individual spores is often very curious, probably owing to mutual pressure in their crowded position. These spores can germinate almost at once, sending out one 
or two hyphae in various directions (Figs. 5 and 9), relatively only a few of which are successful in penetrating an algal filament. Fig. 5 shows a spore which has rather thicker walls than is usual in this species; such spores are occasionally to be found.

As already mentioned, this mode of formation of the spores does not account for their occasional position within the layers of the Tolypothrix-sheath (Fig. I). Such a position can be accounted for by assuming spore-formation to have taken place on a mycelial branch, ramifying in the sheath of the Alga. Such mycelial branches undoubtedly occur, but I have never observed a formation of spores in them.

In a few individuals certain parts of the parasitic hyphae were seen to be very much more swollen than others (Fig. I8); such swollen portions may possibly develop into internal spores, analogous to those of $R$. nodosa, Dang., but I have as yet been unsuccessful in following up their further fate. They were especially observed in material grown in a solution of cane-sugar. Since the spores usually formed by $R$. Boodlei are relatively thin-walled and incapable of existing for a long period, it would seem natural that they should only be formed on the external and not on the internal mycelium. For spores, formed in this latter position, must be surrounded for a long time by the empty sheath of the Tolypothrix, and months would ordinarily elapse before this latter would decay and leave the spores lying freely in the water. It is true that the fungal hyphae normally have to penetrate the sheath of the Alga, but it is questionable whether a young, justformed hypha is capable of doing this.

I have had the species described under observation for several months, and have seen no indication of zoosporeformation.

The life-cycle of $R$. Boodlei may be briefly summarized as follows: Mycelial branches, emerging from the internal parasitic hyphae, give rise to large numbers of thin-walled spores. These germinate almost at once, giving rise to one or more hyphae, which attack the host and penetrate into 
its interior. Branches of the internal mycelium also serve to convey the Fungus from one individual to another.

I give the following measurements of this species:-

Diameter of the internal mycelium $=.005-.008 \mathrm{~mm}$.

$$
" \quad " \quad \text { external } " \quad \text { spores }=.012-.015 \mathrm{~mm} \text {. }
$$

A few remarks may be added on the bearing of the facts, described in this paper, on the systematic position of the genus Resticularia. As far as I am aware, the formation of spores on external branches of the parasitic mycelium is a feature as yet unobserved in the Ancylistaceae; and in the two species under consideration this is evidently a common method of propagation. Whereas the species, which I have provisionally united with $R$. nodosa, Dangeard, forms thickwalled chlamydospores, $R$. Boodlei has thin-walled spores, incapable of standing a long resting-period. Undoubtedly this latter species also forms chlamydospores of some kind, enabling it to pass through unfavourable external conditions; and it remains to be seen whether $R$. nodosa does not also form thin-walled spores at some period in its life-history.

Since the observations contained in the preceding pages tend to cast considerable doubt on the sexuality of $R$. nodosa, one of the chief links connecting the genus in question with Ancylistes is removed. According to Pfitzer's description ('72, p. 379), there are undoubted dioecious sexual organs in this latter genus.

In many respects, however, Ancylistes and Resticularia are similar to one another, and it will be best for the present to leave them side by side; although further observations may make it advisable to place the latter genus in a separate section of the Ancylistaceae ${ }^{1}$. Renewed observations may

1 Quite recently v. Deckenbach has published an interesting treatise on a new Fungus parasitic in marine species of Calothrix (Coenomyces consuens, nov. gen. nov. spec., Flora, Bd. xcii, I903, pp. $253-83$, Pl. VI and VII), which further contains a lengthy discussion of the phylogenetic relationships of the Fungi. Coenomyces possesses a well-developed septate mycelium, and is propagated by means of uniciliate zoospores (the only method of reproduction observed); owing to the occurrence of these two characters side by side, which are considered as 
also make it advisable to separate $R$. Boodlei generically from Dangeard's species.

The following is a brief description of the genus Resticularia and its two species:-

Resticularia, Dangeard (emend.).

Mycelium in part endophytic, in part ectophytic. Endophytic mycelium moniliform, with or without transverse septa, occasionally forming chlamydospores; ectophytic mycelium with or without septae, generally strongly branched and forming thin- or thick-walled spores. Other portions of the ectophytic mycelium act as infecting-hyphae. Sporangia formed in the endophytic mycelium, the contents of which are protruded to the outside through the wall of the host and there split up into a small number of zoospores, the latter rather large and uniciliate.

$R$. nodosa, Dangeard (emend.).

Endophytic mycelium (diam. 4-6 $\mu$ ) usually septate, and forming numerous chlamydospores (diam. 6-9 $\mu$ ), ectophytic mycelium very fine (diam. $\cdot 5^{-\mathrm{I}} \mu$ ), much branched, forming numerous chlamydospores, singly on lateral branches. Infecting-hyphae rare. Endophytic mycelium commonly branched. Zoospores occasionally formed. In the filaments of Lyngbya aestuarii (Dangeard!) and Tolypothrix sp. (mihi!). R. Boodlei, Fritsch, n. sp.

Endophytic mycelium (diam. 5-8 $\mu$ ), with occasional septa ; ectophytic mycelium relatively broad (diam. I.5-5 $\mu$ ), much

characteristic of the higher and lower Fungi respectively, a new division, Coenomycetes, is established for the reception of the genus Coenomyces, and to this Aphanistis must probably also be referred. This division is thought to occupy an inter-. mediate position between Phycomycetes and Eumycetes, although originating from an independent stock. The space at my disposal does not allow of a detailed discussion of these views, but the existence or non-existence of transverse walls in a fungal mycelium does not appeal to me as a point of great importance. In Resticularia nodosa, Dang., for instance, the internal mycelium is distinctly septate, whilst in $R$. Boodlei septation only occurs in connexion with the dying out of the hyphae; in this latter species, however, the external mycelium at the time of sporeformation is distinctly septate. I have not yet observed the zoospores of these two species (cf., however, Dangeard for $R$. nodosa), but their discovery would seem to me to necessitate the inclusion of this genus in the Coenomycetes, if further investigation warrants the maintenance of this group. (Note added July 6, 1903.) 
branched, forming numerous large thin-walled spores (diam. I 2-I $5 \mu$ ), generally in a chain on lateral branches. Infectinghyphae abundant. Endophytic mycelium rarely branched. Zoospores not observed. In the filaments of Tolypothrix, sp.

It only remains for me to acknowledge the kind assistance of a friend in the preparation of the figures for this paper.

\section{University College, London.}

March 6, I903.

\section{REFERENCES TO LITERATURE.}

Dangeard ('90): Recherches histologiques sur les Champignons. Le Botaniste, $2^{\mathrm{e}}$ sér., I890-I, pp. 96-9, Pl. IV, Figs. 24-3I.

Fischer ('92): Rabenhorst's Kryptogamenflora v. Deutschland, Oesterreich u. der Schweiz. Erster Band, 4. Abtheilung, Phycomycetes, I892.

Lemmermann ('01): Die parasitischen $u$. saprophytischen Pilze der Algen. Abh. Nat. Ver. Brem., I90I, Bd. xvii, Heft I, pp. 185-202.

Pfitzer ('72): Ancylistes Closterii, ein Algenparasit aus der Ordnung der Phycomyceten. Monatsber. der Königl. Acad. d. Wissensch. zu Berlin, I 872, p. 379 .

Schröter ('93) : in Engler-Prantl, Natürl. Pflanzenfam., I. Teil, I. Abtheilung, I 893, p. 92 . 


\section{DESCRIPTION OF FIGURES IN PLATE XXIX.}

Illustrating Dr. Fritsch's paper on Fungi parasitic on Tolypothrix.

Figs. I-18. Resticularia Boodlei, n. sp.

Fig. I. Two spores, lying in the mernbrane of the Tolypothrix, from which epiphytic hyphae have arisen. $\times 600$.

Fig. 2. A spore has germinated, giving rise to a short endophytic mycelium. $\times 600$.

Fig. 3. Fully-developed parasitic hypha, showing moniliform constrictions; at $a$, an external branch is developing. $\times 750$.

Fig. 4. The same; shows a further stage in the development of the external branch. $\times 750$.

Fig. 5. A spore has germinated at both ends; one of the hyphae thus formed has penetrated a filament of the Alga, giving rise to a parasitic, moniliform hypha in both directions. From the internal mycelium an infecting-hypha has branched off. $\times 750$.

Fig. 6. A spore has germinated; the parasitic mycelium has formed three infecting-hyphae. $\times 75^{\circ}$.

Fig. 7. Oily granules are seen in the mycelium; also an infecting-hypha. $\times 750$.

Fig. 8. The Fungus has died off behind and has become septate in the dead portion; in front the mycelium is not constricted, but forms a straight tube. $\times 750$.

Fig. 9. Spore germinating; the penetrating hypha has spread out in both directions along the algal filament. The latter has formed thick protecting-walls, a little way in front of the present position of the parasite. $\quad \times 75^{\circ}$.

Figs. Io, II. Infection from one individual of the host to another. The dead posterior portion of the parasite has become septate. $\times 750$.

Fig. 12. Reinfection of same filament; see explanation in text. $\times 75^{\circ}$.

Figs. I3, I4. Evasion of the protecting-walls formed by the Alga. $\times 75^{\circ}$.

Fig. 15. Reinfection and fusion; see explanation in text. $\times 75^{\circ}$.

Fig. I6. Formation of spores on the external mycelium, early stages. The arrow indicates the point at which the main hypha continued and joined on to the endophytic mycelium. $\times 75^{\circ}$.

Fig. I7. The same; further advanced stage. The entire external mycelium has given rise to spores. $\times 560$.

Fig. I8. At $s p$. internal spores are possibly developing. $\times 750$.

Figs. 19-29. Resticularia nodosa, Dangeard (?).

Fig. 19. This shows the ordinary appearance of the parasitic mycelium, which terminates at one of the heterocysts of the Alga. The cell-contents of the latter are contracted about the Fungus. $\times 600$.

Fig. 20. The same; a chlamydospore has developed within the heterocyst. $\times 600$.

Fig. 2I. A chlamydospore is developed in the course of the internal mycelium. $\times 600$.

Figs. 22, 23. Show chlamydospores; in Fig. 22 they alone remain. $\times 600$. 


\section{Fritsch.-Two Fungi on Tolypothrix.}

Fig. 24. The internal mycelium branched; a chlamydospore has been formed on the simple portion. $\times 600$.

Fig. 25. Internal mycelium branched; an infecting-hypha has been developed. $\times 760$.

Fig. 26. Two chlamydospores are growing out to form long external hyphae. $\times 750$.

Fig. 27. Young stages in the formation of external chlamydospores. $\times 750$.

Fig. 28. Later stages in chlamydospore-formation. $\times 75^{\circ}$.

Fig. 29. An isolated chlamydospore with a portion of the external mycelium. $\times 760$. 


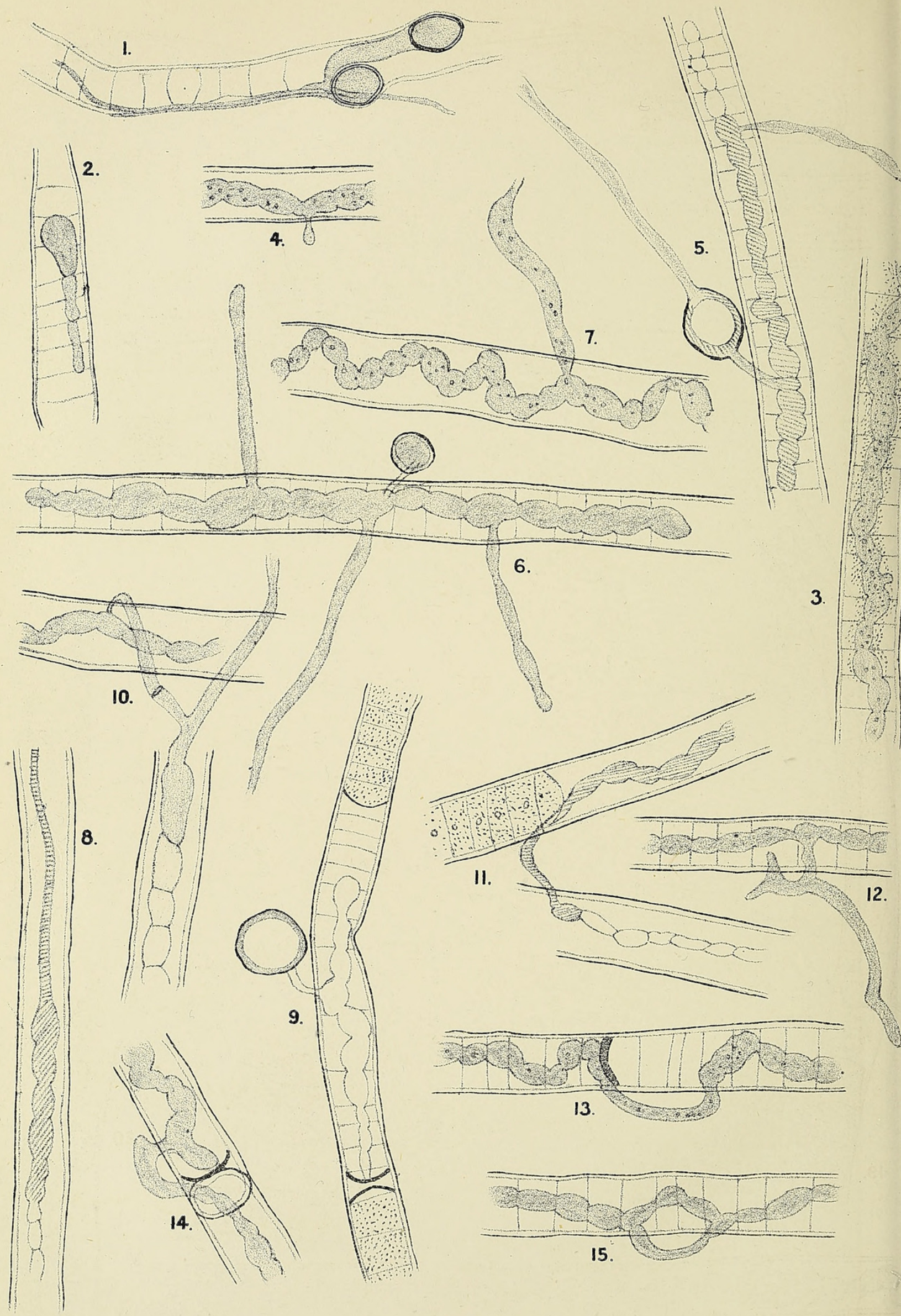

H.L and F.EF, del 

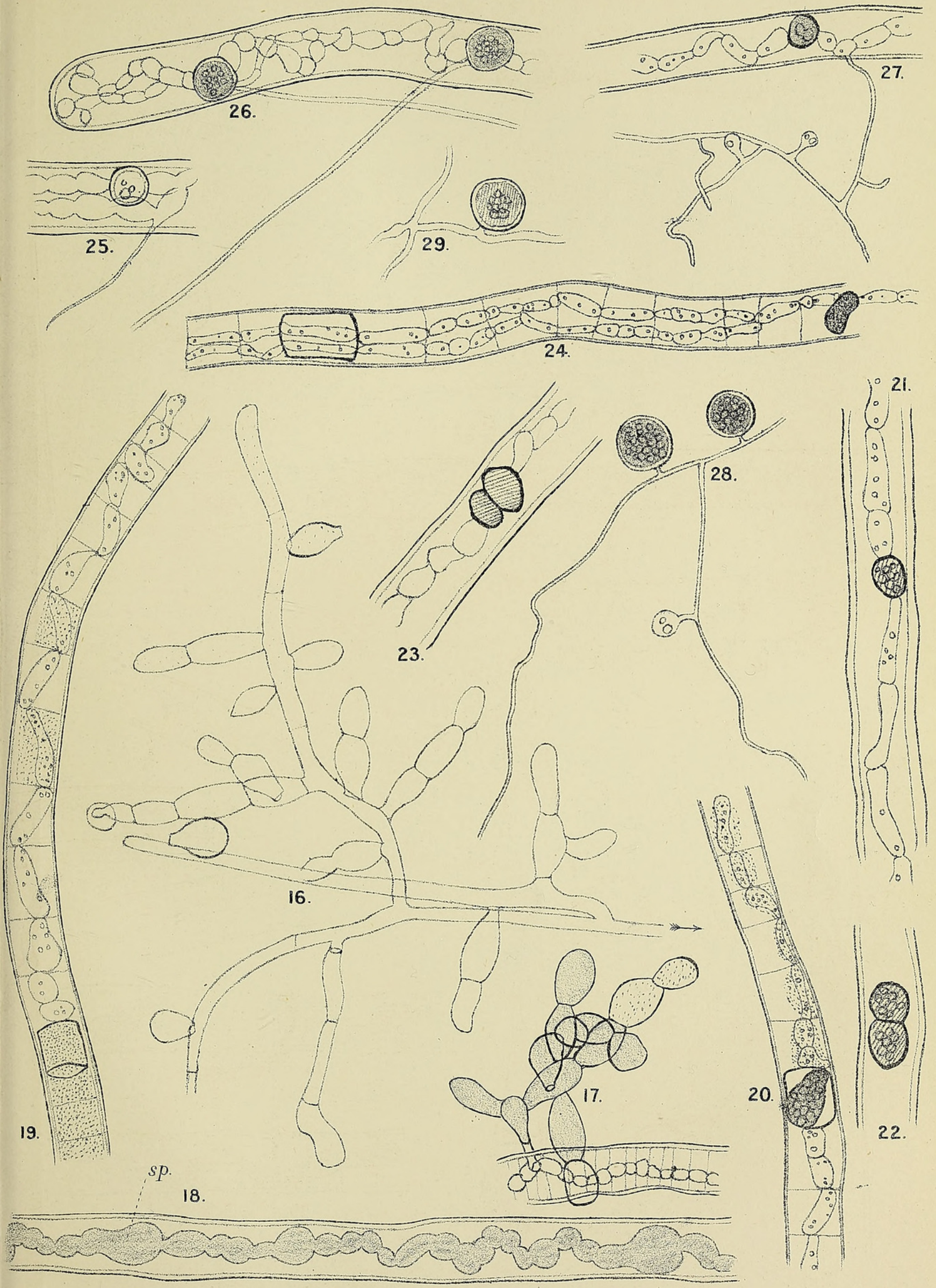


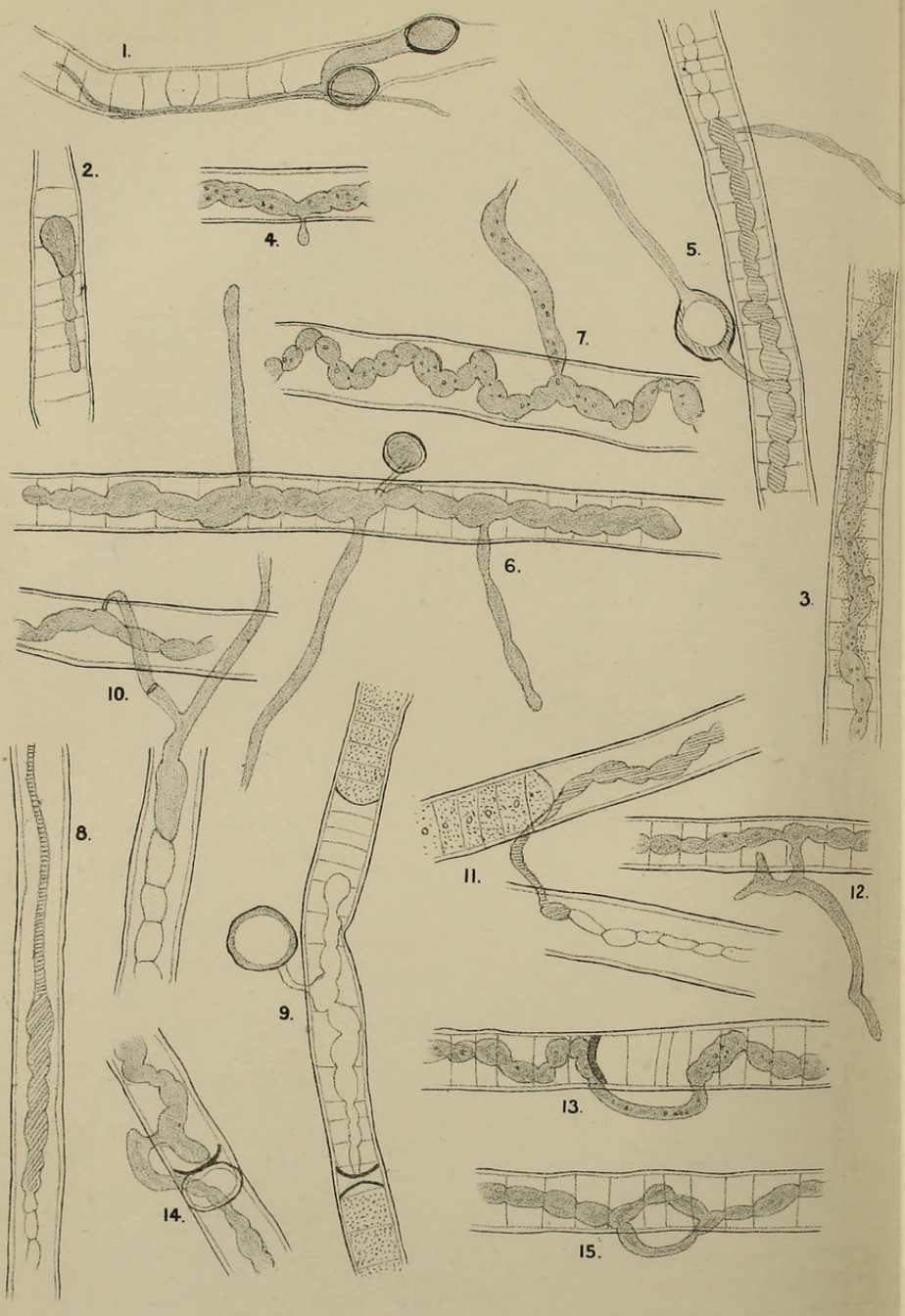

H.L. and F EF, del
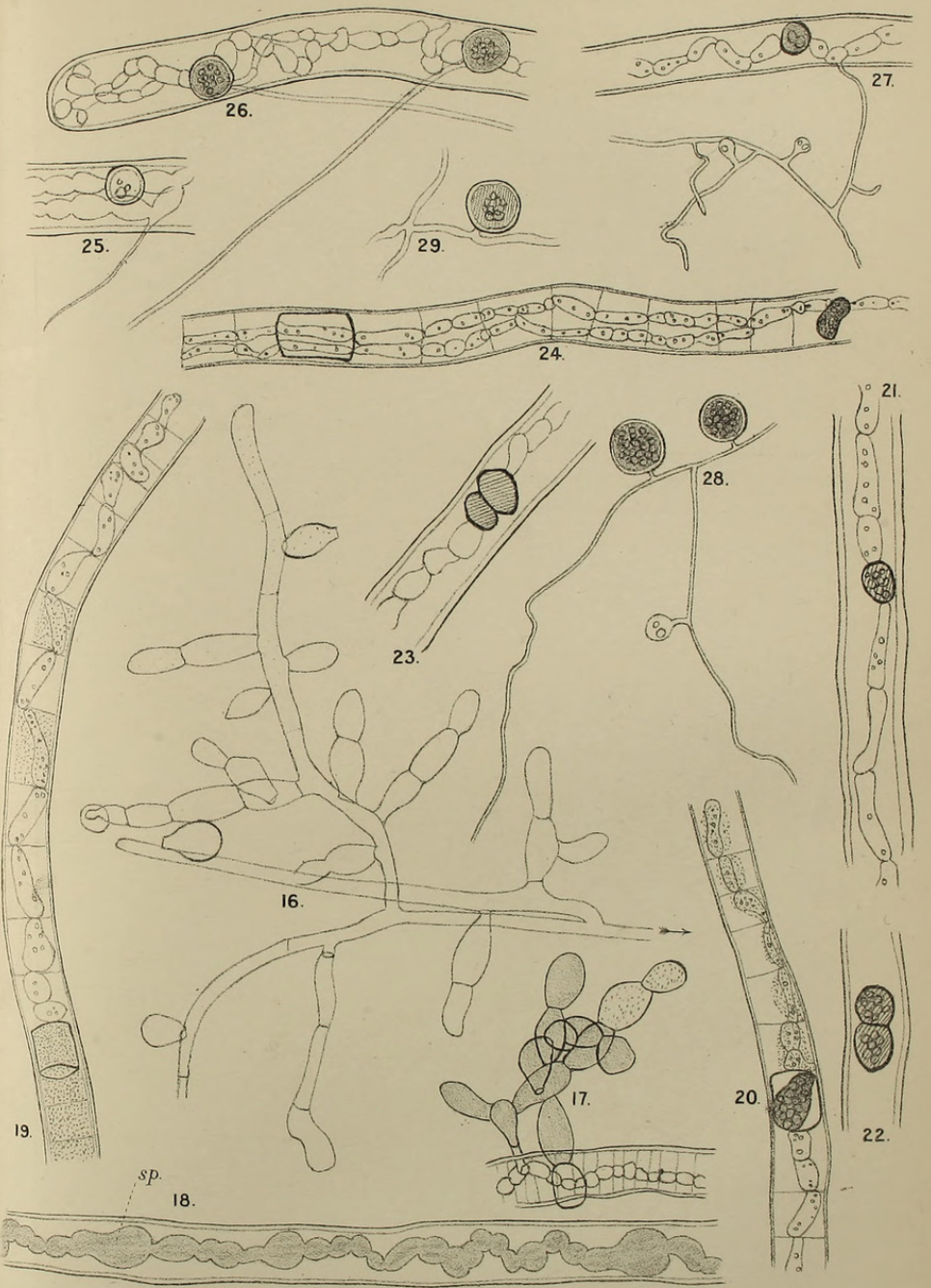

University Press, 0xiord. 


\section{$2 \mathrm{BHL}$ Biodiversity Heritage Library}

Fritsch, Felix Eugene. 1903. "Two fungi, parasitic on species of Tolypothrix (Testicularia nodosa, Dang. and R. boodlei, n. sp.)." Annals of botany 17, 649-664. https://doi.org/10.1093/oxfordjournals.aob.a088938.

View This Item Online: https://www.biodiversitylibrary.org/item/235015

DOI: https://doi.org/10.1093/oxfordjournals.aob.a088938

Permalink: https://www.biodiversitylibrary.org/partpdf/318736

\section{Holding Institution}

Smithsonian Libraries

\section{Sponsored by}

Biodiversity Heritage Library

\section{Copyright \& Reuse}

Copyright Status: Not in copyright. The BHL knows of no copyright restrictions on this item.

This document was created from content at the Biodiversity Heritage Library, the world's largest open access digital library for biodiversity literature and archives. Visit BHL at https://www.biodiversitylibrary.org. 